\title{
Alexander Vashkevich
}

European Humanities University, Vilnius, Lithuania

alexander.vashkevich@ehu.It

ORCID: 0000-0003-1886-4010

https://doi.org/10.26881/gsp.2020.4.03

\section{Judicial “Independence" in Belarus: Theory and Practice}

I expect the German legal profession to understand that the nation is not here for them but they are here for the nation... From now on, I shall intervene in these cases and remove from office those judges who evidently do not understand the demand of the hour (Adolf Hitler, address to the Reichstag, 26 April 1942). ${ }^{1}$

We have been carefully watching the rulings judges made when the tax agency went to court. We will make the final analysis, and if there are unsatisfactory rulings - ones not in favor of the state - we will take respective measures according to the legislation...

How is it possible that many of the judges of the capital did not appear in the media or labor collectives last year?

I seriously warn the Minister of Justice and the heads of courts about their personal responsibility for the state of affairs in this area. (From a speech given by Alexander Lukashenko, President of Belarus, 5 December 1997). ${ }^{2}$

And about the courts. Many people want and in the judicial community itself some independence.

Although I am ready to argue with anyone that the most independent court is in Belarus.

Let no one laugh.

(From a speech given by Alexander Lukashenko during a meeting with the Chairman of the Supreme Court of Belarus, 31 August 2020). ${ }^{3}$

1 H.P. Graver, "Why Adolf Hitler Spared the Judges: Judicial Opposition Against the Nazi State”, German Law Journal 2018, no. 4, p. 846.

2 The First Congress of Judges of the Republic of Belarus: Documents and Materials, Minsk 1998, pp. 21, 41.

3 https://www.belta.by/president/view/lukashenko-poprosil-sukalo-podkljuchitsja-k-rabote-poobnovleniju-konstitutsii-404842-2020/(accessed: 2020.09.11). 


\section{Introduction}

On 9 August 2020, presidential elections were held in Belarus. They were rife with unprecedented fraud and gross violations of electoral legislation before and during election day and included refusing to register opposition candidates, totally excluding independent observers, an incredible $42 \%$ of votes cast early, ${ }^{4}$ jailing two opposition candidates and forcing another to flee the country. On the evening of election day immediately after polling stations closed, Belarusian state television aired exit poll results in which Alexander Lukashenko received $80.23 \%$ of the votes, while Svetlana Tikhanovskaya - the main opposition candidate - received only $9.9 \%$. The next day, the Central Election Commission of Belarus announced the preliminary results of Belarus's presidential election; the incumbent president, Lukashenko, who has occupied his post for 26 years, received $80.23 \%$ of the votes. ${ }^{5}$

These incredible figures and the refusal of many local electoral committees to report to the people waiting near the polling stations the real voting results, which is contrary to electoral legislation, sparked a wave of peaceful protests. During the period of 9-11 August, almost 7,000 protesters were detained, and a significant number of them were subjected to degrading treatment, violence and torture by law enforcement agencies and special troops while being transported to detention facilities and in them. At least four people were killed, and hundreds were severely injured and required urgent medical attention. ${ }^{6}$

Belarusian society was shocked by the electoral fraud and a level of violence that was comparable only to the Nazi occupation of the country during the Second World War. Several high-ranking officials resigned in protest, including the Belarusian ambassador to Slovakia and the Chargé d'affaires in Switzerland. ' Some high and low ranking policemen, law enforcement officers and military personnel also applied for early retirement ${ }^{8}$ despite some lacking only a few months more of service to be granted a very good pensions. However, not one of the country's 1,239 judges resigned. Moreover, judges who conducted administrative proceedings against the beaten, dirty, hungry and often humiliated detainees in detention facilities failed to react to their dire condition, visible injuries or testimony of ill-treatment. ${ }^{9}$ Administrative proceedings during

\footnotetext{
4 http://rec.gov.by/sites/default/files/pdf/2020/d_gol.pdf (accessed: 2020.09.22).

5 https://www.belarus.by/en/press-center/news/preliminary-election-results-lukashenko-gets8023-of-votes_i_0000117252.html (accessed: 2020.09.22).

6 See for instance: UN human rights experts: Belarus must stop torturing protesters and prevent enforced disappearances, https://www.ohchr.org/EN/NewsEvents/Pages/DisplayNews.aspx?NewsID=2 6199\&LangID=E (accessed: 2020.09.22).

7 https://news.tut.by/economics/697024.html (accessed: 2020.09.22); https://www.dw.com/ru/ shoroh-s-mtz-belorusskij-diplomat-o-tom-chto-mozhet-zastavit-lukashenko-ujti/a-54704000 (accessed: 2020.09.22).

8 See for example: https://news.tut.by/society/699280.html\#ua:news_bytime 1 (accessed: 2020.09.22).

9 Belarus - Human Rights NGOs call on torture and arbitrary arrests of peaceful protesters to stop. 24 August 2020 Press Release, https://www.fidh.org/en/region/europe-central-asia/belarus/belarus-
} 
which the participants of the peaceful protests were sentenced to arrest for up to 15 days, lasted from two to ten minutes for each of the accused. Some of them report seeing on a table court decisions that had been prepared in advance. ${ }^{10}$ Not a single person was acquitted.

The aim of this article is to try to answer how it was possible to build such a judicial system, which legal instruments were used in its creation and how the principle of the independence of the judiciary, which is proclaimed in the constitutional legislation of the Republic of Belarus, is implemented in practice.

\section{A brief history of the judicial system of Belarus}

From 1923 until the end of 1991, the Republic of Belarus was part of the Soviet Union, in which neither the notion of "judicial power" nor the principle of separation of powers existed. Although art. 88 of the Constitution of Belarus of $1937^{11}$ and the similar art. 154 of the Belarusian Constitution of 1978 proclaimed that judges and lay judges are independent and subject only to the law, ${ }^{12}$ in practice the courts have not been independent. "Courts are independent and subordinate only to the law and (...) to the District Committee of Communist Party of the Soviet Union" was a famous saying in Soviet times. All state bodies including courts were subordinated to the governing bodies of the Communist Party, which was the only party in the Soviet Union and was officially named "the leading and guiding force of Soviet society and the nucleus of its political system, of all state and public organizations."13 All serious decisions made by judges had to be approved in advance by local Communist Party apparatchiks. This process was widely known as "telephone justice." The Soviet concept of the "independence" of judges was nicely described by an author of a textbook for the students of law faculties:

The independence of Soviet judges cannot be understood as independence from the socialist state. The court is an organ of the state and as such cannot be independent from the entity to which it belongs. The Soviet court cannot serve other purposes than those of a socialist society; it cannot implement policies other than those of the Communist Party and the Soviet Government. ${ }^{14}$

human-rights-ngos-call-on-torture-and-arbitrary-arrests-of (accessed: 2020.09.22).

$10 \mathrm{https}: / /$ soundcloud.com/user-761067396/vypusk-10-pravosudie-za-5-minut-kak-sudili-na-okrestina (accessed: 2020.09.22).

11 https://pravo.by/pravovaya-informatsiya/pomniki-gistoryi-prava-belarusi/kanstytutsyynae-prava-belarusi/kanstytutsyi-belarusi/konstitutsiya-1937-goda/ (accessed: 2020.09.22).

12 https://pravo.by/pravovaya-informatsiya/pomniki-gistoryi-prava-belarusi/kanstytutsyynae-prava-belarusi/kanstytutsyi-belarusi/konstitutsiya-1978-goda/ (accessed: 2020.09.22).

13 Art. 6, Constitution of Belarus 1978, http://actbssr.pravo.by/WorkDoc/ShowDoc?RegNum= Y07810000 (accessed: 2020.09.22).

14 Moscow 1948, p. 84. 
Local court judges were "elected" by citizens for three years (there was always one candidate for each vacant position), while judges of the Supreme Court of Belarus were elected by the Supreme Soviet for five years.

After the collapse of the Soviet Union, it became obvious that transforming the judicial system was necessary to bring it in line with the new reality and international standards.

The Declaration of State Sovereignty of Belarus was proclaimed on 27 July 1990, and from 25 August 1991 Parliament granted it the highest legal force in the hierarchy of legal acts. ${ }^{15}$ For the first time in the history of Belarus this document established the norm according to which "[T] he separation of legislative, executive, and judicial power shall be the most important principle of the functioning of the Republic of Belarus as a rule of law state." ${ }^{16}$ On 23 April 1992, the Parliament endorsed the Concept of the Judiciary and Legal Reform outlining a step-by-step program of reforming the legal system of Belarus, including establishing an independent judiciary as the principal guarantor of rights and freedoms of individuals and the effectiveness of laws. ${ }^{17}$ A new Constitution of the Republic of Belarus was adopted in March 1994. It confirmed the principle of the separation of powers, incorporated the notion of the judicial branch of government and recognized its independence (art. 6 of the Constitution). Chapter 5 of the Constitution The Judiciary proclaims the following fundamental constitutional principles of the judiciary:

1) judicial power shall rest with the courts (art. 109, part 1 of the Constitution);

2) the judicial system shall be based upon the principles of territorial delineation and specialization (art. 109, part 2 of the Constitution);

3) the creation of special courts shall be prohibited (art. 109(3) of the Constitution);

4) the administration of justice shall be based on the Constitution, laws and other normative legal acts enacted in accordance with them (art. 112 of the Constitution); in administering justice judges shall be independent and subordinate to the law alone. Any interference in the activities of judges in the administration of justice shall be impermissible and liable to legal action (art. 110 of the Constitution);

5) judges may not be members of political parties or other public associations that pursue political goals (art. 36(2) of the Constitution);

6) justice shall be administered on the basis of the adversarial proceedings and equality of the parties involved in the trial (art. 115(1) of the Constitution);

7) proceedings in all courts shall be public, except for instances prescribed by law (art. 114 of the Constitution);

8) the parties and participants of judicial proceedings have the right to appeal rulings, sentences and other judicial decisions (art. 115(3) of the Constitution).

15 Official Journal of the Supreme Council of the Belorussian SSR 1991, No. 28, art. 425 (Viedomosti Vierchovnoho Sovieta Biełorusskoj SSR).

16 Art. 7 of the Declaration of State Sovereignty.

17 Official Journal of the Supreme Council of the Republic of Belarus 1992, No. 16, art. 270. 
These principles were enshrined and further developed in the Law on the Judiciary and the Status of Judges. ${ }^{18}$ However, a striking contrast between the letter of the law and the practice of its application, or, as Prof. Olimpiad S. loffe wrote the "irreconcilable divergence between legal promises and everyday life"19 has always been a hallmark of Soviet law. Unfortunately, in this sense the situation in Belarus remains unchanged compared to Soviet times, and in some ways, paradoxically, it is even worse. Soviet traditions are deeply rooted in minds of the representatives of the legal professions in Belarus, including in the minds of the professors and lecturers at the law faculties. These traditions were supported and maintained by the first (and only) President of Belarus, Lukashenko, who was elected four months after the first Constitution of independent Belarus was adopted. In 1995, 1996 and 2004, he organized and won (with many violations of the law) three referendums that proposed changes to the Constitution. The binding force of the 1996 referendum was pronounced unconstitutional in a Conclusion of the Constitutional Court, ${ }^{20}$ but Lukashenko ignored it. The referendums were also condemned by international organizations including the Parliamentary Assembly of the Council of Europe and the OSCE Parliamentary Assembly since they fell far short of democratic standards. As a result of the referendums the form of government in Belarus has shifted from a parliamentary democracy with a strong president to a super-presidential republic without the rule of law, no real separation of powers and the absolute power of the president. Lukashenko sincerely believes that the best form of government is that in which the head of the state stands above all other branches of government and can control and influence all of them but not vice versa. As early as in 1995 he openly spoke about his credo in the interview to the German newspaper Handelsblatt:

Germany was raised from ruins thanks to firm authority of well-known figure Hitler (...) German order evolved over the centuries and attained its peak under Hitler. This is perfectly in line with our understanding of a presidential republic and of the role of its president (...) Hitler formed Germany due to the strong presidential power (...) Germany rose thanks to this strong force, thanks to the fact that the whole nation united around its leader (...) The head of state is the president, his influence, his leading role is the main thing (...) The history of Germany teaches us this. ${ }^{21}$

It is important to bear this in mind in order to understand the current situation of judicial independence in Belarus.

18 Official Journal of the Supreme Council of the Republic of Belarus 1995, No. 11, art. 120.

19 O.S. Ioffe, Soviet Law and Soviet Reality, Kluwer Academic Publishers 1985, p. 1, p. 5.

$20 \mathrm{http} / / / \mathrm{kc}$. gov.by/document-11453 (accessed: 2020.09.20).

21 https://charter97.link/en/news/2009/9/11/21887/ (accessed: 2020.09.20). 


\section{Structure of the judicial system in Belarus}

The judicial system of Belarus consists of two pillars. The first one is the Constitutional Court, which is composed of the Chairman, Deputy Chairman and ten judges. The Constitutional Court of the Republic of Belarus is a judicial body tasked with reviewing the constitutionality of normative legal acts and to ensure the supremacy of the Constitution.

The second pillar consists of the courts of general jurisdiction that adjudicate on civil, criminal, economic and administrative cases. The system of courts of general jurisdiction is organized into three tiers and is structured according to the administrative division of the country, i.e., it is based on the principle of territorial jurisdiction. The lowest tier is represented by district and city courts. The second tier includes six oblast courts of general jurisdiction and the Minsk city court plus six oblast courts and one Minsk economic court. At the top of the system of courts of general jurisdiction stands the Supreme Court, which consists of the Chairman, First Deputy Chairman, deputy chairmen (currently 4 ) and 58 judges. The total number of judges working in the country as of the end of August 2020 was 1,239. ${ }^{22}$ Around $60 \%$ of all judges are women. Judges under the age of 30 make up $4 \%$, from 30 to 40 years old - 32\%, from 40 to 50 years old $-33 \%$, from 50 to 60 years old $-25 \%$, over 60 years old $-6 \%$ of the total number of judges (excluding Supreme Court, where, for obvious reasons, the average age of judges is higher). ${ }^{23}$

\section{Selection of Judges}

According to the Constitution of Belarus, "the grounds for electing (appointing) judges and removing them from office shall be determined by law."24 The law in question is the Code on the Judiciary and Status of Judges which sets out the requirements for candidates for the positions of judges. Persons are eligible for judge positions, if they:

1) have reached 25 years of age;

2) possess knowledge of the Belarusian and Russian languages;

3) have graduated from university with a degree in law;

4) have at least three years of professional experience calculated in accordance with the rules determined by the Government of the Republic of Belarus or by a designated government agency;

5) are of good moral character;

22 https://www.sb.by/articles/osmyslennoe-dvizhenie-vpered.html (accessed: 2020.09.20).

23 Composition of judges in courts of general jurisdiction by age and sex as of 24 April 2019, http:// www.court.gov.by/ru/infografika/5829facd9e3e4458.html?version=print (accessed: 2020.09.20).

24 Art. 36(2) of the Constitution of the Republic of Belarus. https://www.constituteproject.org/constitution/Belarus_2004.pdf?lang=en (accessed: 2020.09.20). 
6) have successfully passed qualification examinations for judge positions.

Candidates for positions of judge at the oblast level or the Minsk city court must have served as judges for at least three years; judges of the Supreme Court must have served as a judges for at least five years. Persons may not be appointed as judges if they have been convicted of a crime by a court verdict which has entered into force; are incapable of performing the duties of a judge for health reasons, the fact of which has been confirmed by a medical statement; or have been limited in their legal capacity or incapacitated by court decisions which have entered into force. ${ }^{25}$

The process of selecting candidates for judicial positions is rather lengthy and complicated. It is regulated by the Code on the Judiciary and by unpublished documents of the Supreme Court of Belarus and consists of several steps. The first is being admitted into the so called "reserve groups". The selection of persons applying for positions of judge in courts of general jurisdiction is conducted by the Supreme Court of the Republic of Belarus and the oblast (Minsk city) courts. In practice, these judges are usually recruited from court staff, such as the secretaries of court proceedings (i.e., members of court staff responsible for ensuring that trials are ready to proceed), heads and members of court chancelleries, assistants to chairmen. Sometimes candidates are chosen from the staff of the local prosecutors' offices and (very rarely) they are recruited from among the members of the bar association.

The second step is to pass a qualification examination designed to "assess the level of professional knowledge and skills, and professional, moral and psychological qualities of persons running for positions of judge."26 The qualification examination is conducted by an examination commission created by the Supreme Court of the Republic of Belarus.

The third step is the decision on the registration of persons as candidates for judges that is taken by the Qualification Commission of Judges created at the oblast level and the Minsk city courts. The same commission recommends registered candidates for appointments as trainee judges.

However, the final approval of all candidates for positions of judge is not made by judicial bodies but by the security services and the Department for Relations with Legislative and Judicial Authorities, Citizenship and Pardon Issues of the Administration of the President. This body submits for the President's consideration proposals on the appointment and dismissal of judges in accordance with the legislation of the Republic of Belarus, assigning qualification classes to them, prepares the relevant acts of the President, develops draft acts of the President on issues related to the activities of (...) judicial authorities. ${ }^{27}$

\footnotetext{
${ }^{25}$ Code of the Republic of Belarus on the Judiciary and Status of Judges, art. 76, https://pravo.by/do cument/?guid=3871\&p0=Hk0600139 (accessed: 2020.09.20).

26 Art. 96(1) Code of the Republic of Belarus on the Judiciary and the Status of Judges, https://pravo. by/document/?guid=3871\&p0=Hk0600139 (accessed: 2020.09.20).

27 A. Kramnik, Course of the Administrative Law of the Republic of Belarus, $2^{\text {nd }}$ ed., Minsk 2006, pp. 322-323.
} 
The usual practice is that before possible appointment a candidate has an interview with the Deputy Head of the Presidential Administration in charge of legal matters. ${ }^{28}$

Thus, the first problematic issue in the process of judicial selection is a lack of transparency. Until 2014, the Ministry of Justice and its regional departments were in charge of judicial selection together with the Supreme and oblast courts, and they regulated this process in detail. These regulations were published and available to everyone. However, since 2014, only the Supreme Court and the oblast courts are formally in charge of judicial selection. This is why all the previous regulations of the Ministry of Justice were abolished, but the new ones adopted by the Supreme Court have not been published. ${ }^{29}$ Secondly, the weak position of the judicial qualification commissions is also problematic; their decisions are only advisory for the executive, who is in full control of the selection process.

\section{Nomination of Judges}

According to art. 84 (8-10) of the Constitution and art. 81 of the Code on the Judiciary, all judges of the courts of general jurisdiction are appointed by the president from among candidates proposed by the Chairman of the Supreme Court of the Republic of Belarus. Judges of the Supreme Court of the Republic of Belarus are appointed by the president with the consent of the Council of the Republic of the National Assembly of the Republic of Belarus (the upper house of Parliament). The president has full and unlimited discretion in the appointments. Several cases have been reported of candidates who were previously recommended by the qualification commissions and were not appointed, but no explanation was given. ${ }^{30} \mathrm{It}$ is also worth noting that even in cases in which the "consent" of the House of Parliament is required, the act of nomination always occurs in advance. Sometimes the decision on consent is issued several months after the nomination. For example, on 1 August 2016 the president nominated Mr. Kovalchuk as a judge of the Supreme Court. ${ }^{31}$ The consent of the Council of the Republic of the National Assembly was given only on 3 October $2016 .{ }^{32} \mathrm{It}$ is necessary to bear in mind that since November 1996, when new version of the Constitution came into force, the Parliament has not rejected any presidential appointees.

One more interesting detail: the six judges of the Constitutional Court are appointed solely by the president. There is no requirement for him to engage in consulta-

\footnotetext{
28 A. Petrash, "The court system in action", Justice in Belarus 2005, no. 8, p. 15.

29 See for example: O. Fedotov, Commentary to the reform of the judicial system of Belarus of 2014, part 3, "Transparency of reform", https://nmnby.eu/news/analytics/5651.html (accessed: 2020.09.20).

30 Independence of the judiciary in the Republic of Belarus, https://belhelcom.org/sites/default/files/ bhc_report_judiciary.pdf (accessed: 2020.09.20).

31 http://president.gov.by/ru/news_ru/view/aleksandr-lukashenko-podpisal-ukaz-o-naznachenii-iosvobozhdenii-sudej-14130/ (accessed: 2020.09.20).

$32 \mathrm{https://www.belta.by/society/view/sovet-respubliki-dal-soglasie-na-naznachenie-andreja-koval-}$ chuka-sudjej-verhovnogo-suda-212911-2016/ (accessed: 2020.09.20).
} 
tions with members of the judiciary or the wider legal community in order to ascertain the most appropriate candidates. Another six judges are formally appointed by the Council of Republic. However, the exclusive right to propose candidates to these positions to the Parliament belongs to the Chair of the Constitutional Court. And who has the right to nominate all chairs of all courts and their deputies in Belarus? According to the Code on Judiciary and Status of Judges this power belongs to the president. ${ }^{33}$ Thus, he has unlimited powers to determine the composition of the Constitutional Court and all other courts in Belarus.

\section{Tenure of judges}

One of the foundations of the independence of judges is their appointment for life. This principle was enshrined as early as in 1780 in the Constitution of Massachusetts, ${ }^{34}$ and this is the gold standard accepted in national and international law. According to the recommendation of the Venice Commission, "judges should be appointed permanently until retirement. Probationary periods for judges in office are problematic from the point of view of independence." ${ }^{35}$ In the early twenty-first century, the legal status of Belarusian judges in this respect deteriorated even in comparison to the previous Law on the Judicial System and the Legal Status of Judges in Belarus, according to which judges were appointed initially for five years and then indefinitely. ${ }^{36}$ According to the current version of the Code on the Judiciary, "judges shall be appointed for a term of five years and may be reappointed for a new term or for life." ${ }^{137}$ Thus, as long as a judge is not appointed for life, every five years he or she can either be reappointed for a new five-year term, or he or she can be dismissed at the expiration of his or her term in office. The appearance of this provision in the Code is likely due to Lukashenko's strongly held belief that the life appointment of judges is a bad idea. He openly expressed this opinion during his speech at the Second Congress of Judges in 2002.

I would like to ask: is the principle of life-long appointments too relaxing for some judges? A judge who is appointed for the first time and serves five years, shows himself from his best side. This is good. But is it right to appoint him to this position indefinitely? In my opinion this is wrong. And do not feel offended. We have violated the conceptual principle of the functioning of the branches of government. Neither the deputies, nor the president, nor other leaders are appointed for life. You can argue with me: what about the practice in other

33 Code on the Judiciary, art. 32(1), art. 33(1), art. 39(1), art. 40(1), art. 41(1), art. 42(1), art. 43(1), https://pravo.by/document/?guid=3871\&p0=Hk0600139 (accessed: 2020.09 .20 ).

34 http://www.nhinet.org/ccs/docs/ma-1780.htm (accessed: 2020.09.20).

35 Report on the independence of the judicial system. Part I: The independence of judges. Adopted by the Venice Commission at its 82 ${ }^{\text {nd }}$ Plenary Session (Venice, 12-13 March 2010), p. 9, https://www. venice.coe.int/webforms/documents/?pdf=CDL-AD(2010)004-e (accessed: 2020.09.20).

36 Official Journal of the Supreme Council of the Republic of Belarus 1995, No. 1, art. 12.

37 Code on the Judiciary, art. 81(3), https://pravo.by/document/?guid=3871\&p0=Hk0600139 (accessed: 2020.09.20). 
countries? But I can name examples of other practices. Firstly, this is not done in all countries. Secondly, do we have objective conditions for the application of such appointment principles? Maybe reappointment should be limited to a period of maximum ten years? Maybe it should be limited to five years ${ }^{38}$ ?

As of early 2009, of the total of 960 judges in general jurisdiction courts, 684 (or 70\%) were appointed for life and 276 were appointed for the first time or reappointed..$^{39}$ In September 2015 this correlation worsened with only 55\% of judges being appointed to positions indefinitely. According to Valery Kalenkovich, Deputy Chairman of the Supreme Court, "This figure can be explained by the fact that the lowerlevel judiciary is quite young, and not all employees have five years of work experience in their positions." ${ }^{\prime 40}$ More recent data is not available, but it is highly probable that the number of judges appointed for life has decreased even further. This conclusion follows from the analysis of decrees on the appointment of judges adopted in 2019. On 31 May, only three judges were nominated for life and 49 were appointed for fiveyear terms. ${ }^{41}$ On 3 October, 65 judges were nominated for five-year terms and only two for life. ${ }^{42}$ Thus, taking into account the crucial role of the executive in the nomination process, the current practice is a real threat to the independence of judges and a violation of the principle of the non-removability of judges.

There is another problematic issue in the nomination procedure. According to the Code on the Judiciary, when judges of courts of general jurisdiction are on social leave, retired judges or other persons may be appointed to these positions, provided that they meet the requirements for candidates for the position of judges of courts of general jurisdiction. ${ }^{43}$ These judges have the same rights and duties as regular judges with one exception: the return of colleagues from maternity leave is the legal basis for their release, unless they are appointed to other vacancies in the same or other courts. This is a clear violation of the principle of the non-removability of judges.

\section{Remuneration, Benefits and Privileges}

One of the most important tools that permits directly influencing judges is the right of the president to set the amount of their remuneration and to provide them with affordable or free housing. The remuneration of judges, like that of other civil

38 The Second Congress of Judges of the Republic of Belarus, Minsk 2002, p. 29.

39 A. Vashkevich, "Judicial Independence in the Republic of Belarus" [in:] Judicial Independence in Transition. Beiträge zum ausländischen öffentlichen Recht und Völkerrecht (Veröffentlichungen des MaxPlanck-Instituts für ausländisches öffentliches Recht und Völkerrecht), ed. A. Seibert-Fohr, vol. 233, Springer, Berlin, Heidelberg 2012.

40 https://www.spok.by/novosti/vsya-lenta/sudeiskii-korpus-belarusi-na-57-sostoit-_ naaaa0002057-057 (accessed: 2020.09.20).

41 https://pravo.by/document/?guid=12551\&p0=P31900209\&p1=1 (accessed: 2020.09 .20 ).

$42 \mathrm{https} / / /$ pravo.by/document/?guid=12551\&p0=P31900366\&p1 $=1$ (accessed: 2020.09 .20 ).

43 Art. 8 1(3), Code on the Judiciary, https://pravo.by/document/?guid=3871\&p0=Hk0600139 (accessed: 2020.09.20). 
servants, consists of position-based salary, bonuses for qualification rank and premiums and other payments in accordance with the law. The salaries of judges are set by the Head of the State as a percentage of the salary of the President of the Supreme Court in an unpublished special addendum to the Presidential Ordinance. ${ }^{44}$

In addition to monetary compensation for their work, judges are entitled to a variety of other benefits, including the right to improve their housing conditions before other persons who are registered in line (people who are officially registered as "in need of improving housing conditions" can get housing for half the price compared with the free market). ${ }^{45}$ Moreover, judges are entitled to expedited subsidized loans for the construction (reconstruction) or purchase of housing. Judges requiring improvement of housing conditions are entitled to rent housing for the term of their office from the state housing fund. All these benefits are very important, as the most acute problem for young professionals is the lack of accessible housing. Since the presidential administration and organs of local executive power are responsible for the distribution of these benefits, there is always room to influence judges. In considering the fifth periodic report of Belarus, the UN Human Rights Committee expressed concern that the salaries of judges are determined by presidential decree rather than by law. ${ }^{46}$ Additionally, it recommended to Belarus to take all measures necessary to safeguard, in law and in practice, the full independence of the judiciary, including by: (a) reviewing the role of the President in the selection, appointment, reappointment, promotion and dismissal of judges; (b) considering establishing an independent body to govern the judicial selection process; and (c) guaranteeing judges' security of tenure. ${ }^{47}$

\section{Role of the presidents of the courts}

The Chairman of the Belarusian court is definitely not the primus inter pares. He or she (and his or her deputy) is appointed by presidential decree, which also designates his or her remuneration and prospects for his or her professional career and promotion. In particular, decisions are taken monthly regarding the amounts of the so called "additional incentive payments" to judges, which make up a substantial part of the salaries. Moreover, one of the disciplinary actions that judges can be subject-

44 Ordinance of the President of the Republic of Belarus No. 625 of 4 December 1997, Concerning the improvement of remuneration of judges and the improvement of assets, technical and staffing situations of the courts of the Republic of Belarus, Collection of Decrees and Ordinances of the President and Resolutions of the Government of the Republic of Belarus 1997, No. 34, art. 1070 with amendments.

45 Par 1.11, Ordinance of the President of the Republic of Belarus No. 195 of 3 April 2008, Concerning some social and legal guarantees for military personnel, judges and prosecutors, National Registry of Legal Acts of the Republic of Belarus 2008, No. 83, 1/9603, No.248, 1/10104.

${ }^{46}$ Concluding observations on the fifth periodic report of Belarus, 22 November 2018, CCPR/C/BLR/CO/5, https://tbinternet.ohchr.org/_layouts/15/treatybodyexternal/Download. aspx?symbolno=CCPR/C/BLR/CO/5\&Lang=En (accessed: 2020.09 .20 ).

47 Ibidem. 
ed to is the "deprivation in whole or in part of additional incentive payments for up to 12 months".48 The final decision on whether judges should be punished or not is also assigned to the head of the court. Discretion in these matters is a potential threat to judicial independence.

According to the Code on the Judiciary and the Status of Judges, the task of assigning incoming cases lies not with a computer program but with the president of the relevant court or with the deputy president of that court if the president is temporarily absent. ${ }^{49}$

Taking into account the role of the head of Belarusian courts to assign cases, to decide about remuneration for judges, their careers and tenures, it is safe to conclude that this is a tool used by the executive for ensuring that judges are obedient.

\section{Disciplinary proceedings}

Disciplinary proceedings against judges of general jurisdiction courts are handled by relevant Qualification Commissions of Judges. However, their decisions are only non-binding recommendations to the chairman of the court who has the last say in every case. The disciplinary sanctions that can be imposed on judges include issuing notices, reprimands, warnings regarding inadequate compatibility with the requirements of the position occupied, withholding in whole or in part additional incentive payments for up to 12 months, reducing qualification ranks for a period of up to six months, removal from the bench. It is worth noting that according to art. 102 of the Code on the Judiciary, on the grounds set out in this Code, the President of the Republic of Belarus may impose any disciplinary sanction on any judge without initiating disciplinary proceedings. ${ }^{50}$ Although it has not been necessary to use this instrument in practice, this is just another example of the weapons the executive has at its disposal just in case the usual mechanisms to ensure obedience from judges fail.

It is also good to know that the chair, deputy chair and judges of the Constitutional Court appointed by the president must undergo "an annual, in-depth medical examination at the state-owned Republican Clinical Medical Centre managed by the presidential administration within the timeframe set by the President of the Republic of Belarus", whereas "those guilty of undergoing a medical check-up with delay are subject to disciplinary liability in accordance with established procedure."51

All judges are dismissed by the president.

48 Art. 92, Code on the Judiciary, https://pravo.by/document/?guid=3871\&p0=Hk0600139 (accessed: 2020.09.20).

49 Art. 32, art. 33, art. 39, art. 40, Code on the Judiciary, https://pravo.by/document/?guid=3871\&p0 $=$ Hk0600139 (accessed: 2020.09.20).

50 Ibidem.

51 Decree of the President of the Republic of Belarus No. 32 of 18 January 1999, "On medical examination and certification of senior officials of state bodies whose positions are included in the personnel register of the Head of State of the Republic of Belarus" (amended and supplemented as of 18 January 2018). 


\section{Constitutional Court and its "independence"}

Under the Constitution of 1997, the Constitutional Court is included in the system of the Belarusian judiciary. (Previously, the legal status of the court was enshrined in the chapter of the Constitution devoted to the organs of state control and supervision). Everything that has been written thus far in this article about the legal status of judges of general courts is applicable to the judges of the Constitutional Court. The only difference is that judges of the Constitutional Court hold office for 11 years and can be reappointed or re-elected to this position after the expiration of their previous terms. Some facts characterizing the role of the Constitutional Court and its "independence" speak for themselves.

Since 1997, not a single legal act adopted by the president has been recognized as fully or partially unconstitutional.

Since 2008, the Constitutional Court has reviewed over a thousand draft laws through the procedure of preliminary review. None of them has been found to be contrary to the Constitution.

At the same time, on 25 August 2020 the Constitutional Court adopted, on its own initiative, an act known as the "Constitutional Legal Position on the Protection of the Constitutional Order."52 In this document the court expresses the opinion that the presidential election of the Republic of Belarus of 9 August 2020 was free, democratic, and legitimate, and that Lukashenko was legally elected President of Belarus. Moreover, it proclaimed that the Coordination Council, an organ created by Belarusian people for establishing a dialog with the authorities, is an unconstitutional body because it was allegedly established "in an way that is not provided for by the Constitution or electoral laws." This document is an extremely awkward, unconstitutional attempt to legitimize the actions of the law enforcement agencies for the criminal persecution of the members of the Coordination Council. The Constitution and Belarusian legislation do not foresee that a Constitutional Court act such as this is a "constitutionally legal position." Besides, this court lacks the legal power to even start any legal procedures on its own initiative. Finally, it has no power to make judgments on the legality of presidential elections.

Thus, the Constitutional Court is only a decorative body that masks the absence of a real separation of powers in Belarus and is fully dependent on the will of the president.

\section{Conclusion}

The independence of the judiciary is one of the most important features of a democratic state based on the rule of law and a basic element of the right to a fair trial. This

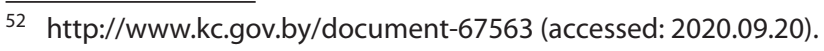


principle has been widely enshrined both in the national legislation of many states and in international law. Since the Republic of Belarus has gained independence, several attempts have been made to create an independent judiciary. A number of guarantees for the independence of judges were provided for in the Concept of Judicial and Legal Reform and in the 1994 Constitution. However, in 1995, the process of radically strengthening presidential power began that led to the creation of the super-presidential form of government and a consolidated authoritarian regime. Currently, the courts are not an independent branch of government and are totally dependent on the president, his administration and his secret services. The selection of judges, their appointment and dismissal from office, promotions and remuneration are entirely dependent on the will of one person. As long as Lukashenko remains in power, under no circumstances is it possible to create independent judiciary in Belarus.

\section{Literature}

"Belarus - Human Rights NGOs call on torture and arbitrary arrests of peaceful protesters to stop," 24 August 2020, Press Release, https://www.fidh.org/en/region/europe-central-asia/ belarus/belarus-human-rights-ngos-call-on-torture-and-arbitrary-arrests-of (accessed: 2020.09.20).

Fedotov O., Commentary to the reform of the judicial system of Belarus of 2014, art 3.

Graver H.P., "Why Adolf Hitler Spared the Judges: Judicial Opposition Against the Nazi State", German Law Journal 2018, no. 4.

loffe O.S., Soviet Law and Soviet Reality, Kluwer Academic Publishers 1985, p. 1, p. 5.

Kramnik A., Course of the Administrative Law of the Republic of Belarus, $2^{\text {nd }}$ ed., Minsk 2006.

Petrash A., "The court system in action", Justice in Belarus 2005, no. 8.

Report on the independence of the judicial system. Part I: The independence of judges. Adopted by the Venice Commission at its $82^{\text {nd }}$ Plenary Session (Venice, $12-13$ March 2010), p. 9, https://www.venice.coe.int/webforms/documents/?pdf=CDL-AD(2010)004-e (accessed: 2020.09.20).

"Transparency of reform", https://nmnby.eu/news/analytics/5651.html (accessed: 2020.09.20).

"UN human rights experts: Belarus must stop torturing protesters and prevent enforced disappearances", https://www.ohchr.org/EN/NewsEvents/Pages/DisplayNews. aspx?NewsID=26199\&LangID=E (accessed: 2020.09.20).

Vashkevich A., "Judicial Independence in the Republic of Belarus" [in:] Judicial Independence in Transition. Beiträge zum ausländischen öffentlichen Recht und Völkerrecht (Veröffentlichungen des Max-Planck-Instituts für ausländisches öffentliches Recht und Völkerrecht), ed. A. SeibertFohr, vol. 233, Springer, Berlin, Heidelberg 2012. 


\section{Summary}

\section{Alexander Vashkevich}

\section{Judicial “Independence” in Belarus: Theory and Practice}

The aim of the article is to understand the reasons why the Belarusian judicial system is totally dependent and to show the legal mechanisms that were used by the executive to achieve this. The creation of a super-presidential form of government and authoritarian political regime gave the president of Belarus crucial influence on the judiciary through the processes of selecting, appointing and reappointing and dismissing judges, and determining their remuneration and social packages.

Keywords: Constitutional court, general jurisdiction courts, independence of judges, judicial system, president

\section{Streszczenie}

\section{Alexander Vashkevich}

\section{„Niezależność" sądownictwa na Białorusi: teoria i praktyka}

Celem artykułu jest ustalenie przyczyn całkowitej zależności białoruskiego wymiaru sprawiedliwości od władzy wykonawczej, jak również wskazanie mechanizmów prawnych, którymi posłużyła się władza wykonawcza, aby uzależnić od siebie sądy. Wprowadzenie prezydenckiej formy rządów i autorytarnego reżimu politycznego zagwarantowało prezydentowi Białorusi kluczowy wpływ na wymiar sprawiedliwości poprzez procedury wyboru, powoływania, ponownego mianowania i odwoływania sędziów, jak również ustalania ich wynagrodzeń i pakietów socjalnych.

Słowa kluczowe: sąd konstytucyjny, sądy powszechne, niezawisłość sędziów, system sądownictwa, prezydent 